Article

\title{
From Closed to Claimed Spaces for Participation: Contestation in Urban Redevelopment Induced- Displacements and Resettlement in Kigali, Rwanda
}

\author{
Alice Nikuze *(D), Richard Sliuzas $\mathbb{D}^{\mathbb{D}}$ and Johannes Flacke $\mathbb{D}$ \\ Faculty of Geo-Information Science and Earth Observation (ITC), University of Twente, P.O. Box 217, \\ 7500 AE Enschede, The Netherlands; r.sliuzas@utwente.nl (R.S.); j.flacke@utwente.nl (J.F.) \\ * Correspondence: a.nikuze@utwente.nl
}

Received: 19 May 2020; Accepted: 29 June 2020; Published: 1 July 2020

\begin{abstract}
In many cities and urban areas in Africa, land acquisition for urban redevelopment, land readjustment, and resettlement of affected urban residents are currently framed as innovative approaches to eradicating informal settlements, improving the living environments, and supporting the implementation of newly adopted city Master Plans. Nevertheless, it is not yet known how the responses of institutions and affected people shape these processes. Based on research conducted in Kigali, Rwanda, this article discusses affected residents' responses to land expropriation and resettlement necessary for urban redevelopments. Our findings show that affected informal settlement dwellers voiced their concerns over the deviations from the Expropriation Law, compensation decision-making made behind closed doors, lack of transparency in property valuation, and compensation packages that they perceive to be unfair. Some of the consequences of these concerns are strong feelings of unfairness, exclusion, and marginalisation; distrust and increased perceptions of impoverishment risks, all of which fuel contestation and resistance attitudes among the affected landowners. The affected landowners agitate to assert their rights and stake their claims through contestations, community mobilisation, and legal recourse. We conclude that such contestations constitute claimed spaces and interactions in which affected landowners are laying claim to fair processes against the "exceptionality" and the "decide-defend" decision-making approaches, while local authorities assert legitimacy of their decisions. Critically, informal households affected by urban redevelopments see opportunities for participation in their resettlement decision-making as fundamental to securing their future.
\end{abstract}

Keywords: urban redevelopment; land acquisition; expropriation; induced-displacement; resettlement; spaces for participation; compensation; right claiming; contestation; Kigali

\section{Introduction}

Urban redevelopment of existing inner-city settlements promises macro-level benefits in cities and towns in the Global South, but also carries the threat of displacement and dispossession of the local landowners, including many from existing informal settlements. In several cities, redevelopment projects are increasingly implemented to achieve multiple and varied goals including eradicating unplanned settlements, improving the quality of urban housing stocks, and more generally improving the urban living environments $[1,2]$. The implementation of such urban redevelopment projects often necessitates the clearance of old neighbourhoods, that are often attractive to investors. That in turns leads to land acquisition processes and the relocation of poor people living in such urban areas [3-7]. In some countries, the power of eminent domain or land acquisition for the public interest is used as justification for the acquisition of land for such urban redevelopment projects $[7,8]$. 
Urban redevelopment projects involving land acquisition and resettlement processes are usually opposed by local landowners [9-12]. However, in many African cities current urban redevelopment and population displacement are justified as being in the public interest and are framed as necessary, urgent, and inevitable [13]. In cases of land acquisitions and resettlement processes claimed to be in the public interest, scholars have argued that affected people struggle to be relocated under better conditions and to safeguard their rights [4,14]. Previous studies have reported people's resistance attitudes in such resettlement processes. First, people facing displacement are more likely to contest resettlement decisions if they have strong perceptions of impoverishment risks inherent in the project [15]. Such perceived impoverishment risks, which are an outcome when adequate compensation and livelihood rehabilitation programs are not offered, stimulates local residents' resistance. Second, the lack of participation in decision-making by the people to be displaced or resettled usually causes local resistance to development projects [16,17].

Governments in several developing countries have established legal frameworks to provide adequate safeguards, ensure effective participation, and protect people's rights, including those to fair compensation to those affected by resettlement in the public interest [18]. However, empirical studies reveal gaps in practices, with statutory procedures not being properly followed in many land acquisition and resettlement projects [19-22] leading to the violation of the rights of affected people. Specifically, many urban redevelopment projects and associated resettlement processes often follow a top-down approach, such that decision-making processes are made in closed spaces and/or through pseudo-participation that fails to reflect the interests of affected people [23,24]. The difficulties that affected people face in challenging or altering such exclusionary decision-making processes have brought citizenship and participation discussions into focus, highlighting the increase in people asserting their rights. In such cases, contestation and resistance are often used by affected people struggling to assert their rights, through collective actions such as petitions and legal actions among others, exercised outside the state sanctioned spaces for participation, to assert their claims $[12,15,16]$. Scholars argue that the analysis of how all these spaces for participation are created provides an opportunity to explore how people engage with the processes that affect their lives and how they claimed spaces for participation through resistance or acceptance behaviours [25]. Despite the current increasing expansion of urban redevelopment and displacement of the poor in African cities, empirical studies into local responses to these urban transformations remain scarce [6]. Therefore, studies that shed light on the created spaces for participation and illuminate the dynamics of the relationships and bargaining power between the affected people and powerful actors would be worthwhile [26].

Against this background, the aim of this paper is to examine the affected landowners' responses to practices of participation by state actors to achieve implicit motives in urban redevelopment and resettlement in Kigali. This African city is an ideal case to study. Largely driven by the ambition of implementing its Master Plan, Kigali has embarked on massive urban redevelopment projects involving compulsory land acquisitions in long-standing informal settlements [8,27]. Recently, the local authorities introduced a policy of in-kind compensation (in the form of replacement houses) as a strategy that will not only benefit the informal settlement households affected by land acquisitions but also will help to quickly achieve other urban priorities such as increasing the housing stock for low-income people and eradicating informal settlement proliferation in the context of implementing Kigali's Master Plan. Since compulsory housing compensation in urban redevelopment and renewal projects in Kigali remains new [28], little is yet known about how the responses of institutions and affected people are shaping these processes, nor about the dynamics of interactions between local authorities and the affected people.

\section{Urban Redevelopment, Land Acquisition, and Spaces for Participation}

In the Global South, urban redevelopment projects continue to be a popular strategy for improving living standards and the environmental conditions in urban areas. Urban redevelopments include the replacement of existing old housing by new, usually high-density buildings that follow current 
architectural trends. Proponents of this approach, mostly using the theory of "deconcentrating poverty districts", believe that redevelopment projects can contribute to economic development and improve the quality of life of residents living in depressed urban areas. This will benefit people by, for instance, locating new houses outside of disaster risk locations [29]. However, critical scholars, challenge the value and impacts of redevelopment projects pointing to their role in causing undesirable relocation of low-income urban communities, mostly informal settlements dwellers [30,31]. Several studies have reported that such relocation processes often result in unequal socio-economic consequences, including the risk of impoverishing affected people [31-33]. Redevelopment projects are often realised through public-private partnership initiatives [34]. Thus, opponents also see urban redevelopments as neoliberal projects that facilitate market-driven policies that disproportionately benefit powerful actors-investors, credit institutions, and local and central governments, all at the expense of virtually powerless actors such as the affected residents [13,35].

However, in various countries of the Global South governments may use the power of eminent domain to acquire private land when the public sector requires land for development projects, but are legally obliged to compensate those whose land and other resources are taken [36]. In such cases, scholars have argued that the responses of affected people go beyond resistance in its many manifestations to include various "political reactions from below". Such reactions include mobilisation of people struggling to be displaced under better conditions and safeguarding their rights, including adequate compensation and participation in decision-making [4,14]. However, the meaning of "adequate compensation" is inevitably subjective [37]. In addition to direct money payment, other compensation options, such as in-kind or replacement housing or a combination of the two have emerged [38]. Replacement housing compensation is not only about shelter, but also about where the new house will be located to allow the displaced people to rebuild their livelihoods. In many urban resettlements, affected landowners are relocated from the inner city to peripheral locations where they become unable to maintain access to employment. Several studies have argued that such distant relocation often creates impoverishment risks such as the loss of employment and loss of income, etc. $[32,33]$. Thus, value ambiguity is likely to emerge, affecting all these various perceptions of what adequate compensation is among stakeholders. This typically often triggers conflicts and resistance by local residents.

One common recommendation for improving resettlement outcomes is to involve affected people in decision-making about their resettlement. Community participation in resettlement has been claimed by scholars as necessary to mitigate fear and misinformation among affected people, build transparency, trust, and to provide the opportunity for community concerns to be heard. Such participation is an effective strategy to mitigate conflict that can arise from the varying interests of stakeholders [2,23,39-41]. It is argued that in the absence of participation, even the best resettlement plan will fail [42]. Specifically, in projects involving the redevelopment of existing communities, scholars argue that community participation—also known as public participation-encourages awareness and improves both community consciousness and a sense of ownership of project outcomes [43]. Of course, these benefits imply a critical requirement for people to participate effectively in decision making that affects their lives. Therefore, governments in several countries have established legal frameworks mandating participation in decision-making by those affected by land acquisitions in the public interest [18,44]. Arnstein's ladder of participation [45], which has been adapted by several scholars [46-49] has been used to describe participation levels within an implicit normative assumption that places the forms of participation on an axis going from a non-participation level to a high level of control over decision making. However, despite legal requirements for effective participation in many national legal frameworks, scholars continue to report that such participation remains rare and passive in many land acquisition and resettlement projects $[12,16]$. Scholars have highlighted that administrative adaptation, with respect to the interests of implementers and bureaucratic politics, plays a major role in such exclusionary practices in the Global South. Governments face the dilemma of creating environments that secure the rights of affected people and environments that protect interests 
of investors in current urban land acquisition processes [50,51]. Neoliberal ideology is reported to drive the unwillingness or inability of states to protect the interests of residents [52]. This has implications on issues for spatial justice, transparency, and accountability [53]. The state authorities often choose to use "exceptionality" measures [54] that lead to the violation of rights, including the right to participation, thus leading to social conflict and resistance [21,22,51].

The difficulties faced by affected people in challenging or altering such exclusionary decisionmaking have brought citizenship and participation discussions into focus. These discussions have refocused attention on the formal and informal processes through which rights are asserted, including alternative spaces for practicing citizenship outside a top-down organizational structure $[55,56]$. In this context, Gaventa [25] presented tripartite dynamically related "spaces for participation" (1) closed, (2) invited, and (3) claimed to represent "all opportunities, moments and channels where people can act to potentially influence decisions which affect their lives and interests". In many development projects, decision-making spaces remain closed as citizens often have no say in decisions taken by powerful decision-makers behind closed doors [12]. Within efforts to open up closed spaces, invited spaces are created - channels in which the state offers citizens the opportunity to participate in decision-making processes [57]. However, spaces for participation are usually constrained by actors' power and interests, determining who participates and which discourse is legitimate within such spaces $[25,58,59]$. Thus, invited spaces that are usually seen as favours given by the powerful to the powerless are controlled by those who created them and often serve only the purpose of legitimizing the acts of the powerful [60]. In the absence of genuine participation in such invited spaces, affected people may create other alternative spaces of participation outside the hegemonic space in order to voice their concerns. Within such alternative spaces known as claimed spaces, also known as "popular" spaces because they result from popular initiatives [61], citizens come together as autonomous agents to create opportunities to directly confront the authorities and the status quo in the hope of bringing about changes and resistance to the dominant power relations [62]. The notion of claimed spaces involves a multitude of tactics and strategies deployed by mobilised people claiming rights in diverse ways and seeking to address the challenges of asserting citizenship. Often such mobilisations, which depend on the structural opportunities and constraints in a particular political context, trigger actions in various forms such as contestations, appeals, and legal battles, that have been categorized in several categories such as everyday forms of resistance; social protest or confrontational mobilisation; and struggles through the judicial system and other "political reactions from below", within the aim of overturning some decisions that are perceived as unjust. These "claimed" spaces are also termed "spaces of insurgent citizenship" [63]. The three types of participation spaces discussed evoke opportunities shaped through the exercise of agency, in which various actors' interests and attitudes interact and in which room can be made for alternative decisions. Cornwall [57] argued that people who advocate just, inclusive, and participatory processes need a deep understanding of actors' interactions, interests, and micro-politics.

\section{Research Context}

In 2007, a conceptual Master Plan was developed by US and Singapore consultants to guide the socio-spatial transformation of Kigali city and published, and later approved by the central government in 2009. That Master Plan embodied the city's vision to become a destination for business and investment, as one priority in its agenda for economic development [64]. To help achieve that vision, the Master Plan explicitly suggests a radical transformation of Kigali into a slum-free city, so as to create a modern and "model" city [65]. Given the rapid and largely unplanned growth of the city which took place well before the Master Plan design, major spatial transformations of already developed areas would lead to the displacement of many people, the majority being old informal settlement dwellers. It is relevant to make clear that informal settlements in Kigali mean "unplanned" settlements that lack basic services and adequate sanitation, but where most landowners have land titles that were offered during the land formalisation process in 2009 to legally recognise their property ownership. 
However, some of these informal settlements are located in areas delineated as high risk and undevelopable zones [64]. Thus, the government officials in Kigali often advance environmental health and disaster risk mitigation as motives to clear informal settlements. Such clearance is intended to create a safe and clean environment that attract investors as the main goal of the most Master Plans in many African countries [6]. In Kigali, the better-off landowners and tenants in such high-risk zones have been persuaded to relocate themselves while the vulnerable and poor receive government support to relocate. Thus, small-scale, yet frequent resettlement processes of such poor people have been taking place and sponsored by the government in Kigali districts since 2000. During the implementation of such preventive resettlements of poor households, resettlement sites are selected and developed by district officials in Kigali city, who allocate the new houses, once completed, to the selected beneficiaries. However, those beneficiaries do not normally have any opportunity to participate in the planning and decision-making processes affecting their relocation.

On the other hand, many other informal settlements in Kigali occupy prime land that is attractive to investors for real estate development. Such settlements are in other cases targeted by redevelopment projects and land acquisitions justified as being in the public interest through joint public and private efforts $[8,66]$. The Rwandan constitution is the primary legal instrument that governs access to land. It recognizes the right to private ownership of land and reserves to landowners' legal right to control their land property and secure benefits from its use (Article 29-32). However, the state has the power to acquire any private land and where necessary transfer it to private companies in the public interest. This mechanism is known as expropriation and is regulated by the Expropriation Law 2015 [67]. The landowners whose land is taken have a legal right to a "fair" compensation. In fact, the Master Plan design was accompanied by a new Expropriation Law enacted in 2007 and revised in 2015. That legislation gives the state powers of compulsory land acquisition in the public interest. It provides a clear definition of public interest projects that also includes "any activities to implement land use and development master plans". This clause has been interpreted by the City of Kigali officials, through its constituent districts, to include current urban renewal projects and redevelopment of land occupied by informal settlements [33,66]. As Goodfellow [8] has argued, the Expropriation Law gives incentives to investors to lobby the City of Kigali officials to consider property redevelopment projects as in the public interest (as far as the Master Plan is concerned), a support they need, given the high cost of land at market price and other land ownership issues that they may face during land acquisition.

In previous land acquisition processes in Kigali, affected people were given the option to choose between direct financial compensation and replacement housing. However, the majority of the affected people preferred cash compensation because they perceived the houses to be expensive with stringent terms for bank loans that were offered to them and other concerns such as small size of plots and houses; and they considered the resettlement site to be too far from the Kigali city centre [68].

Recently, local authorities introduced a policy that replacement houses will be the only compensation that will be provided to displaced informal settlement dwellers in Kigali. They argue that this policy is a strategy to systematically eradicate informal settlements proliferation, transform the lives of affected households, increase the housing stock for low-income people, improve the living environment, and support Master Plan implementation. In an interview with the local media (See https://mobile.igihe.com/abantu/interviews/article/imishinga-ikomeye-iteganywa-uko-yakiniyeikipe-y-igihugu-n-ibindi-ikiganiro), the former mayor of Kigali City said that cash compensation only allows affected households to create informal settlements elsewhere within the city. This policy of housing compensation for informal settlement dwellers affected by current urban renewal projects is being implemented through two resettlement options: On-site resettlement and off-site resettlement. In the former, an investor acquires land for investment into affordable housing and uses part of it to construct houses to compensate the affected landowners, a process known as land sharing (see [69]). Under the latter option, the affected people are relocated to another site. These urban redevelopment-induced resettlement projects in Kigali are currently being challenged by strong resistance from affected slum dwellers [70]. 


\section{Materials and Methods}

In this section, we present the research sites and discuss the methods applied for data collection and analysing. This research was carried out in two research sites: Kangondo and Mpazi. The data collection was carried out in two phases: May-September 2017 and March 2019, to better capture how the resettlement processes unfolded in practice and the dynamics of interactions between local authorities and the affected people. Primary data, in the phase, were collected mainly through interviews (of both affected people and government officials) and a focus group discussion with affected landowners. In the second phase, we collected primary data through in-depth interviews with affected people and government officials. For secondary data, we used mainly media resources, including newspapers and videos; and official documents on land acquisition and resettlement (including the national Expropriation Law and informal settlement upgrading strategy).

\subsection{Research Sites}

This study was carried out in two informal settlements: Kangondo and Mpazi, in which the more recent wave of urban redevelopment and informal settlement relocation projects in Kigali City have taken place. Kigali (Figure 1), the capital of Rwanda, is divided into three administrative districts-Gasabo, Kicukiro, and Nyarugenge.

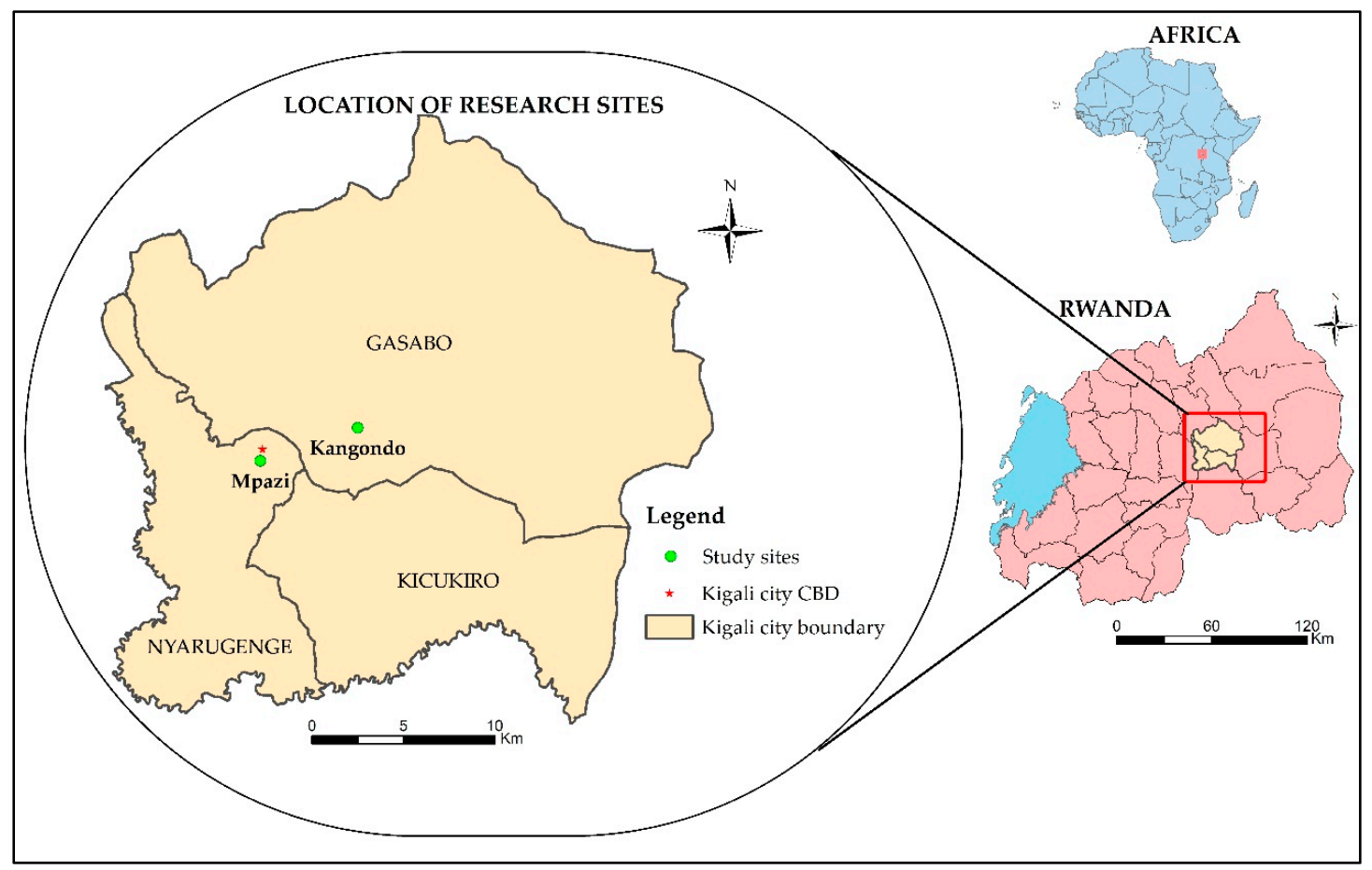

Figure 1. Map of Kigali City and the selected research sites. Source: Authors.

The Kangondo site, located in the Gasabo district (Figure 1), is an area occupied by an established informal settlement and is planned to be redeveloped into a high-end residential settlement. The Kangondo redevelopment project was initiated in 2017 and will lead to a land acquisition process and off-site resettlement of residents to free up land for high-end development (See https://www.ktpress. rw/2018/04/has-kigali-city-failed-to-explain-tobannyahe-residents-the-relocation-plan/). The project is expected to displace approximately 1623 households. In October 2017, a first public meeting took place at which the mayor of Kigali met with the affected people in their neighbourhood. At that meeting, the Kangondo residents were informed about the project, its objectives, and the plan to relocate them to another site, namely Busanza (Figure 2), about $10 \mathrm{~km}$ away from Kangondo. Since then, several other community meetings and exchanges between the affected people and government 
authorities have taken place following the conflicts involved and resistance reactions from the affected people. However, the project implementation started despite discontent among the majority of affected landowners. The construction of the first phase of apartments in three-story building blocks to house the affected households started in March 2018 and approximatively 1040 apartments (Figure 3) are under construction at the selected resettlement site (See https://www.ktpress.rw/2018/04/has-kigalicity-failed-to-explain-to-bannyahe-residents-the-relocation-plan/ ).

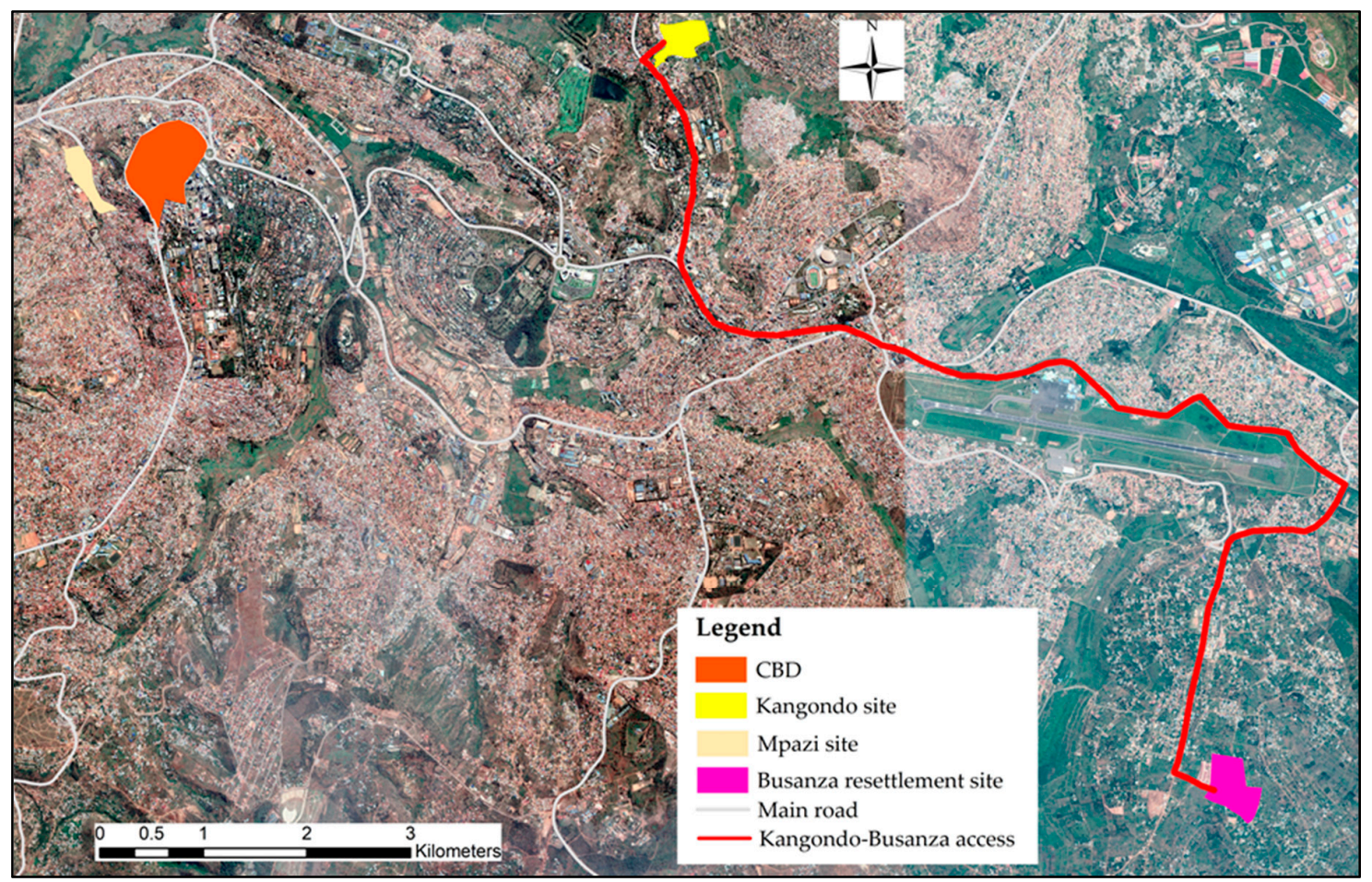

Figure 2. Location of research sites and Busanza resettlement site. Source: Authors.

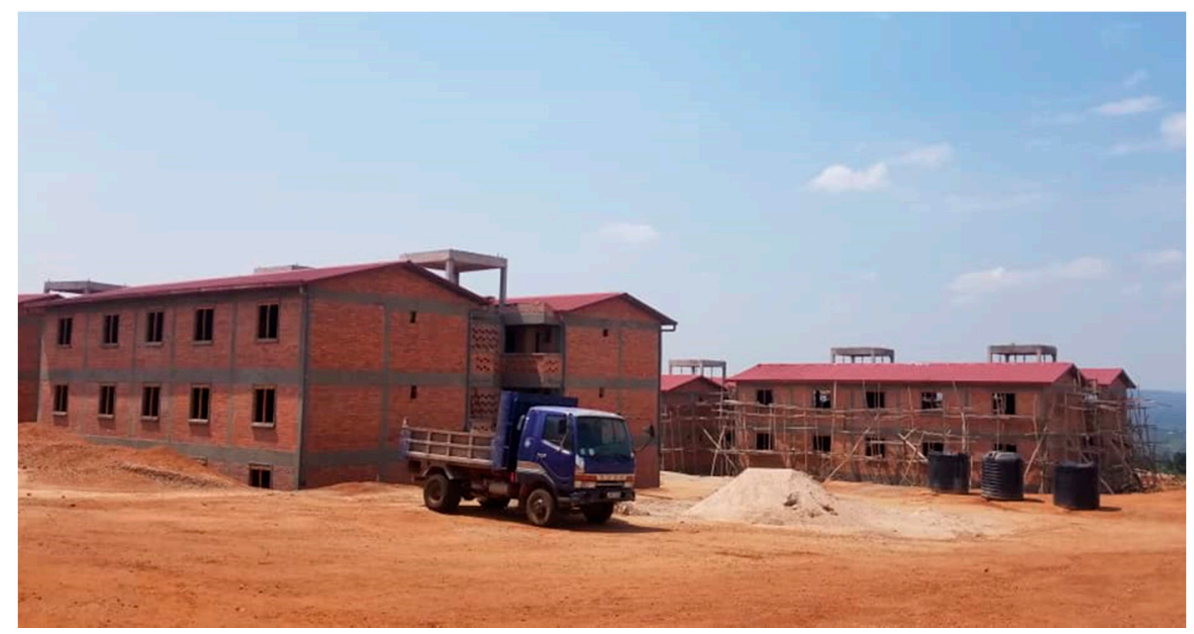

Figure 3. Construction of apartments for Kangondo residents at the Busanza resettlement site. Source: This picture was taken by Ernest Uwayezu in September 2019.

Table 1 is also an informal settlement located very close to the central business district (Figure 2) and is planned to be redeveloped through land sharing leading to on-site resettlement. This project is being implemented under the partnership between the Kigali city authority and private investors. Introduced in 2017, it aims to demolish the Mpazi informal settlement, especially houses located near a water channel, and transfer the rightful landowners to apartment blocks to be built within the same 
neighbourhood. The investors will use part of the demolished area to build houses to compensate affected households and the rest of the land will be used to build affordable housing. In July 2017, the plan to construct first model houses started following the approval of housing typologies proposed to the city of Kigali, Nyarugenge districts, and the Rwanda Housing Authority. The first building block to compensate landowners who accepted the proposal was completed and opened in September 2018. Currently, only three landowners have agreed to participate in the process of land readjustment through the consensual contribution of their land and they have been given apartments in the building shown in Figure 4.

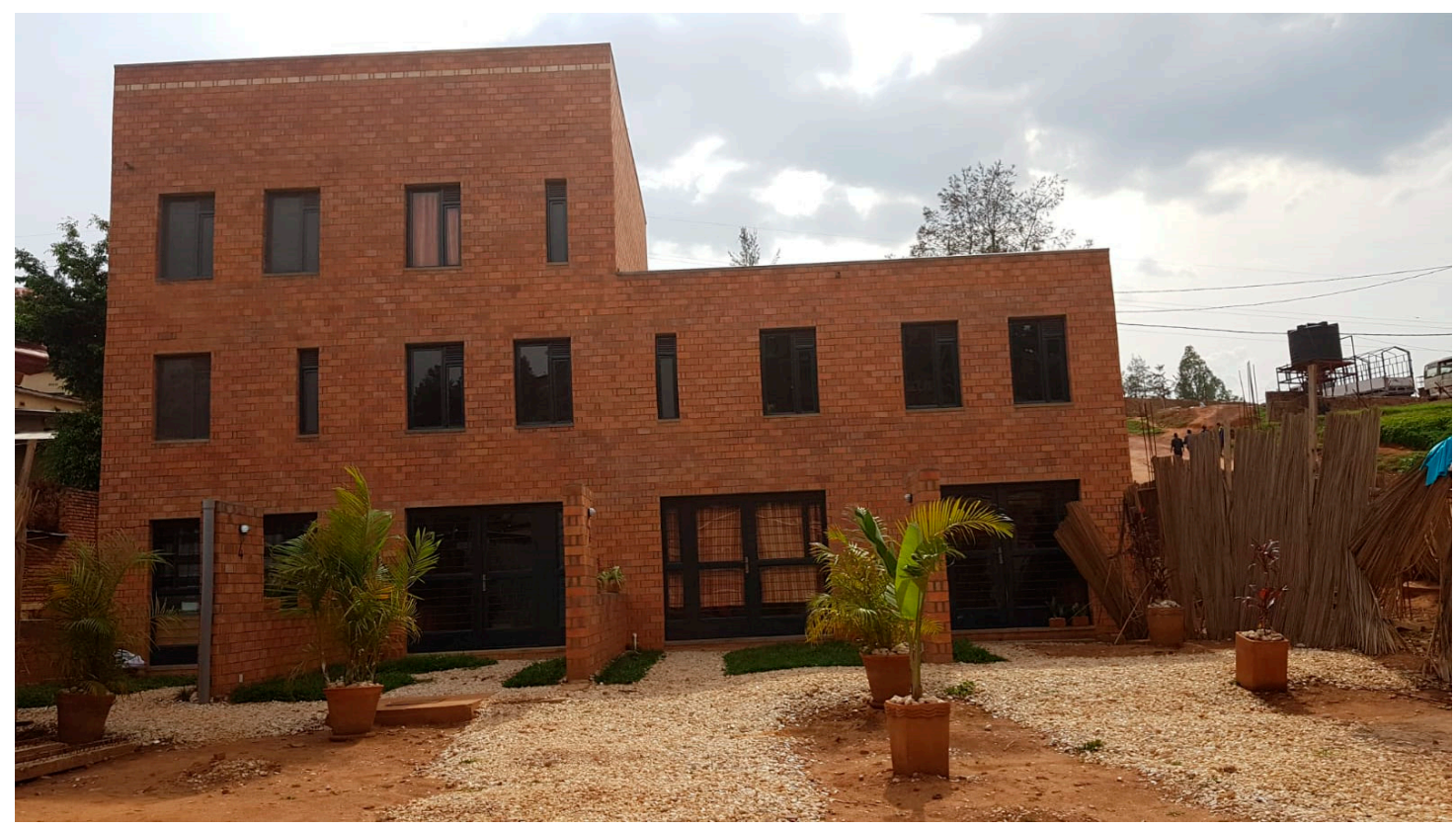

Figure 4. First inaugurated apartment block for affected households at the Mpazi research site. Source: This picture was taken by the first author in March 2019.

Table 1. Overview of research sites.

\begin{tabular}{|c|c|c|}
\hline Research Site & Mpazi & Kangondo \\
\hline Intervention/project & $\begin{array}{l}\text { Demolish old houses and } \\
\text { redevelopment of the area through } \\
\text { construction of apartments } \\
\text { (land sharing-site redevelopment) }\end{array}$ & $\begin{array}{l}\text { Demolish old houses and use the } \\
\text { area for investment in high-end } \\
\text { residential houses } \\
\text { (site redevelopment) }\end{array}$ \\
\hline $\begin{array}{c}\text { Relocation option of affected } \\
\text { households }\end{array}$ & On-site & Off-site \\
\hline Number of affected households * & Unknown & 1623 \\
\hline Status as of (actual date) & $\begin{array}{l}\text { Phase } 1 \text { of apartments to house } \\
\text { affected households completed } \\
\text { Kigali City and Nyarugenge }\end{array}$ & $\begin{array}{l}\text { In construction of all apartments } \\
\text { to house affected households }\end{array}$ \\
\hline Lead agency & District & Kigali City and Gasabo District \\
\hline Sponsorship & $\begin{array}{l}\text { Partnership between Kigali City } \\
\text { and private investors }\end{array}$ & $\begin{array}{c}\text { Partnership between Kigali City } \\
\text { and a private company }\end{array}$ \\
\hline
\end{tabular}

Notes: * Estimated number of households, tenants, and owners to be displaced (Source: Primary reconnaissance).

We selected the above sites for four reasons. First, although these two projects have differences in resettlement options-one being on-site but the other off-site, they were both initiated based on the main motive of supporting the implementation of the Master Plan. Second, these are the first land acquisition projects for which compulsory housing compensation was envisioned. Third, the Kangondo project became the first resettlement case in Kigali that has been characterised by overt resistance and 
contestation between the affected landowners and local authorities. Finally, both projects were still at the early stage of implementation and therefore would allow the gathering of invaluable information on how land acquisitions for urban redevelopment are executed, the responses of affected landowners, and the dynamics of their interactions with local authorities. Table 1 lists the characteristics of both research sites.

\subsection{Data Collection}

In this study, we used data collected from both primary and secondary sources. We collected data during two separate fieldwork trips that took place between May and September 2017 (at the early stage of the projects) and another in March 2019 (advanced stage). In 2017, we collected primary data through a focus group discussion and semi-structured interviews with the heads of affected households and semi-structured interviews with government officials. The first author conducted a focus group discussion on the Mpazi study site and approximately 68 interviews with heads of households in Kangondo and 31 in Mpazi (see Table 2). The focus group included nine participants, a number that was easy to handle and allowed for in-depth discussions. We conducted this focus group discussion and the interviews with the heads of household to gain a general understanding of the level and nature of their participation in the process, their concerns, and their interactions with the local authorities. During this same period, we conducted semi-structured interviews with five government officials in the City of Kigali who have been involved in these types of resettlement processes of informal settlement dwellers, including two project engineers who were directly involved in the Kangondo and Mpazi projects. The interviews with these key informants were conducted to understand the motives, the procedures that were being followed, the participation of affected people, opportunities and challenges in the processes of resettling informal settlement dwellers.

In 2019, we collected more primary data through in-depth interviews, to investigate how the processes unfolded, the spaces for participation, key concerns raised, and the implication on the attitudes of affected households. We interviewed three government officials involved in these two projects as well as 33 heads of household (11 in Kangondo project and 22 in Mpazi project-Table 2). Uniform sets of questions were prepared for interviews with affected communities in both projects to help us identify the similarities and differences between the two cases.

Table 2. Respondents in interviews with head of households.

\begin{tabular}{ccc}
\hline First Fieldwork & No. of HHs (in Sample) & Distribution (\%) \\
\hline Kangondo II & 68 & 69 \\
Mpazi & 31 & 31 \\
Total interviewed HHs & 99 & 100 \\
\hline Second fieldwork & & \\
\hline Kangondo II & 11 & 33 \\
Mpazi & 22 & 67 \\
Total interviewed HHs & 33 & 100 \\
\hline
\end{tabular}

The study also draws on secondary data collected during our fieldwork. These include national laws and regulations governing land acquisition, and the resettlement of informal settlements in Kigali, such as the Expropriation Law and the Informal Settlement Upgrading Strategy Policy (ISUS). Secondary data also include media resources such as newspaper articles and online videos that reported on the two cases.

\subsection{Data Analysis}

For the analysis, first based on the narratives gathered from all data sources, we used conventional content analysis [71] to synthesize information on the projects' implementation in practice, including 
the procedures followed and the motivations, participation of affected people, concerns, reasons for discontent, and resistance among affected people and their strategies.

Second, we analysed the Expropriation Law and the national Informal Settlement Upgrading Strategy (ISUS) to understand the processes of land acquisition and resettlement, including the procedures, compensation, and participation of affected people from the statutory perspective. We finally compared the statutory provisions and the actual practices in the two projects to reveal the extent of deviations from the law. The presentation of our findings also includes verbatim quotations to illustrate actors' perceptions and attitudes. In our opinion, without this in-depth investigation and analysis of the cases, it would be impossible to identify the interactions of affected people and local authorities or reasons underlying the resistance behaviour towards the adopted in-kind (housing) compensation policy among the affected slum residents of Kigali.

\section{Findings and Discussion}

The implementation of the urban redevelopment-induced resettlement projects in the two localities has given rise to various forms of state/citizen actions and counter responses. While these actions and responses vary between the two projects, they centre on concerns related to deviations from the laws, consultation/participation, property valuation, and concerns over compensation packages.

\subsection{Deviations from the Expropriation Law}

The Kangondo and Mpazi projects involved several implementation procedures that raised serious concerns among the affected people. The most contentious matter raised by the affected people was an apparent lack of compliance with the Expropriation Law, the legal instrument currently guiding resettlement for urban redevelopment projects. Affected people raised concerns over procedural flaws that led to non-compliance with its provisions. In the Kangondo project, affected people were surprised to hear that the first communicated compensation plan failed to suggest a property valuation as required by the law. That first approved compensation plan was intended to compensate affected landowners with a new house, with the size determined based only on the land parcel size and not by whatever was built on it. The residents contested this compensation plan and requested the expropriators to first conduct property valuation so as to be able to estimate adequate compensation for losing their existing properties. The affected people refused the compensation estimated based only on parcel size, while the Expropriation Law suggests that the loss of all the land and all developments on it need to be compensated. The residents considered excluding property valuations in the resettlement decision-making as a breach of the law.

Furthermore, while the Expropriation Law stipulates that mutual agreement must be reached between the expropriated and the expropriator over the option of compensation, whether in kind or in cash, affected people raised their concern over the lack of such agreements:

"This law to expropriate people for public interest has not been followed in the planning of this project.... in its article 35, where it says that a fair compensation could be cash or any other compensation that is agreed, there has not been any negotiation and agreement rather a sort of imposition."

The residents blamed the government for depriving them of their rights and circumventing such negotiations and this provided a breeding ground for discontent and then contestation.

In response to the claims of the residents, the authorities took into consideration the protest about incomplete property valuations and determined the claim to be valid. The city officials and the investors agreed to make property valuations that included all developments on the land.

However, contrary to the claim about property valuation state authorities did not consider negotiations on the form of compensation to be valid. When affected people questioned state authorities about why legal provisions were being ignored, one member of the Rwanda senate, in a meeting with Kangondo residents, acknowledged that some provisions in the Expropriation Law were not followed, but ensured them that it was for their benefit and well-being. She stated:

"This is what I am telling you, sometimes, the state does not follow those laws for the benefits of the citizens." 
Previous studies have argued that non-compliance with the Expropriation Law in Rwanda is driven by a lack of administrative and financial capability [66]. However, this study suggests that local authorities are intentionally deviating from some legal provisions. Cleary, Kigali City's officials deliberately ignored negotiations in the form of compensation options, between cash and in-kind, because offering only in-kind compensation was applied as a strategy to decrease the proliferation of informal settlements. However, this motive could not fully explain the lack of compliance with the requirements for property valuation, for instance in the first communicated compensation proposal in the Kangondo case nor the lack of participation by the affected people in the design of the new houses and the selection of resettlement site.

\subsection{Participation in Resettlement Decision-Making}

The Expropriation Law (Article 35) provides that affected landowners should be consulted and be allowed to negotiate with the expropriator about the compensation (either cash or in-kind) before any plans are made. However, in practice this was not done. According to our interviews with key informants, the investors submitted to Kigali city officials the Kangondo project proposal that included the application for expropriation and the compensation plan. The management committee at the city of the Kigali level approved the project as being in the public interest since it supports implementation of the Master Plan. City officials and investors agreed that, as compensation, the residents of Kangondo will be resettled to the Busanza low-cost housing site located in the Kicukiro district, $10 \mathrm{~km}$ away from their existing community. Interviews of both City of Kigali officials and the affected households confirm that neither consultation of nor participation by affected households took place between the plan preparation stage and its approval. After the approval of this proposal, the project was published first through the media and introduced later to the Kangondo community in a public meeting. Similarly to the Kangondo project, residents in Mpazi were not consulted before the approval of all proposals, including the physical development plan of their area and the proposed houses with which they would be compensated. According to our interviews and a focus group discussion, the objectives of the projects and the proposed housing typology were also introduced to the community in a public meeting. In these first public meetings, landowners affected by both projects contested their exclusion in the decision-making, doubting the opportunity to benefit from the projects.

A key informant revealed that because the Mpazi project could not start without access to land, it was necessary to carry out individual negotiations with landowners and convince them to concede their land before construction starts. Thus, before new homes were constructed, negotiations took place regarding house quality (especially size) with respect to family size and expenditures for each landowner with the ambition of implementing the principle of "each according to his needs and ability", i.e., meeting family size and other needs. As a way of allowing these landowners to be able to raise their concerns about the proposed houses, Mpazi project officials organized a field visit to houses similar to the proposed houses. In this visit, landowners had the opportunity to first see and ask questions about the quality of the houses.

Both interviewed resettled households on the Mpazi site and key informants involved in this project confirmed that individual consultation and the visit of the model houses proved to be useful in supporting interactions between the project officers and the landowners in terms of discussing the quality of the houses. The interviewed resettled landowners reported that individual consultations allowed them to negotiate their interests during which they managed to request some changes to the initially proposed houses plans. According to our interviews, the estimates of the compensation (house type) followed the principle of "each according to his/her needs and ability". The new apartments have at least two to three bedrooms and a living room, an inside kitchen, and a bathroom at a cost between seven and sixteen million Rwandan francs (7000-16000 Euro). One resettled landowner, given the range of valuation prices, was able to negotiate more than one house. The resettled landowners also reported that visiting the model house showroom was a good option for them to have an idea of what their new houses will look like to be able to negotiate any desired change. Contrary to the 
Mpazi project, in the Kangondo project while the affected people were still negotiating their interests, the construction of the houses for their compensation started without giving them any opportunity to suggest any change to the initially proposed plans.

The above evidence shows that in both the Kangondo and Mpazi projects, participation evolved from closed to invited spaces with public meetings used as invited spaces. Local authorities in partnership with investors made a series of key decisions regarding compensation in closed spaces without the participation of the affected households. In both Kangondo II and Mpazi, landowners were not involved in or consulted about their compensation decision-making, including the design of the new houses. In Kangondo, in particular, affected landowners were never involved in the selection of their resettlement site. Only when the decisions on the houses' typologies had already been made, were these presented to the affected households in public meetings. This finding reflects other studies that found that compensation decisions are often made behind closed doors [72] and that invited spaces often focus solely on informing the affected communities the decisions made behind closed doors. Some scholars associate such exclusionary practices with perceptions of unfair compensation and injustice $[21,66,73]$. Our study shows that exclusionary decision-making, especially during early stages, not only contributed to the perception of unfairness but also negatively affected the trust of residents in the local authorities leading to strong contestations and resistance in Kangondo towards the entire project.

\subsection{Property Valuation}

In Kangondo, affected households expressed mistrust and suspicion of manipulations in the process of property valuation. Our interviews revealed that the majority of affected households did not agree on the estimated value of their property. Respondents reported satisfaction with the work of enumerators/surveyors because they wrote everything that needed to be considered in the estimation of the property value. However, the majority contested the outcomes of the property valuation, questioning inconsistencies, and expressing the feeling that there were manipulations in values which were communicated to them.

"Example: I received two valuation reports. The first came with 28 million. After two weeks I received another with 30 million. How can that be?"

Another affected head of household in his words pointed to the case of two neighbours who had different estimations of the value of one square meter of land.

"One of the problems we faced ... for me, the unit price of my land is 8000frw per $\mathrm{m}^{2}$, for my neighbour they estimated $12000 \mathrm{Frw}$ per $\mathrm{m}^{2}$. Why this difference since we live in the same neighbourhood?"

These inconsistencies provided a breeding ground for discontent and reinforced the feeling that there was significant manipulation.

"Here they tell us that there was a process of property valuation. But in my opinion, it did not happen. If necessary, our president [of the republic] should know it and I recommend a new valuation process. For instance, I have a house of 3 bedrooms where I live and I have 5 more small houses each of 1-bedroom and a living room. I offered my property for sale, I refused 15 million that was offered to me. But, my property is now valued at 7 million."

The majority of affected households in Kangondo refused to sign consent documents that cited the valuations of their affected property and the corresponding offered replacement house types. Landowners who did not agree with the valuations of their property were given 10 days to do counter-expertise. However, a significant number of the affected households were not able to hire a professional land valuer to carry out this process due to lack of money. Others complained that the time given was too short for them to find money to pay experts. In the Mpazi case, the already resettled landowners did not openly express any concern over inconsistencies, manipulations, and a need to do counter-expertise. However, one respondent who received a new house said that her brother told her that her property was undervalued, although she has reported her satisfaction with the outcome of the property valuation. 
The above attitudes shed light on the concern of affected people about the lack of transparency. German et al. [21] argued that, for instance, no transparency in the property valuation process, with uneven and undisclosed techniques are among the causes of allegations of unfairness that can lead to highly contentious land acquisition processes. Our study confirms that argument. Our interviews with Kangondo residents revealed that affected people were not aware of the standards used in the valuation process and did not trust local authorities. They believed that local authorities and the investors did not change from determining compensation based only on the land parcel size (while ignoring developments on it). The majority believed that the investors made sure that if you, for example, were entitled to a three-room house according to the initial compensation plan, the value of your property would also not exceed the price of the proposed three-room house set by the investors. The affected people accuse property valuers of not being independent and obliged to undervalue property for the benefits of investors and local authorities. This finding has been confirmed by Uwayezu and de Vries [66] who argued that such an undervaluation practice in resettlement processes in Kigali serve only the interests of investors and local authorities who need to minimise the costs of expropriation in case they themselves lack enough funds.

\subsection{In-Kind Compensation: Replacement Houses}

Previous studies identified risk perception among key and universal factors that shape local residents' attitudes towards all kind of projects that affect their lives [74]. Similarly, our interviews with key informants and residents suggest that the majority of affected landlords, mainly the owners of several houses for rent in both Kangondo and Mpazi, were concerned by potential losses of income and impoverishment risks because of replacement houses compensation. They perceive it to be grossly unfair to receive one small flat in exchange for more than three rental houses.

Furthermore, many affected landowners expressed their dissatisfaction with the proposed houses, especially in relation to privacy and overall space compared to the size of their families. The lawyer of 400 elite of resistance explained these concerns in the letter to the minister of local governance:

"... For instance, a landowner whose property value is 18 million will receive a house of 1 bedroom while he/she might have a large family. In case a large family receives such a small house, it shows that informality you are trying to eradicate will shift from an informal settlement to overcrowded housing conditions ... "

Resistance against the in-kind compensation in the form of housing varied within and across the two projects. Although affected people in both projects raised concerns about impoverishment risks, not all of them advanced their complaints through resistance. Some landowners accepted resettlement in new houses, while others resisted both overtly and covertly. There were mixed responses in Mpazi among affected landowners, but strong resistance in Kangondo. Local authorities were challenged, during individual consultations in Mpazi, to find neighbours who had agreed to free enough land to start the project. Only three neighbouring landowners agreed to contribute their land during the first phase. In Kangondo, as disclosed by the district of Gasabo officials, only $10 \%$ of affected households accepted the houses while $90 \%$ were against the replacement houses compensation. Of the $90 \%$ who resist the housing compensation, a group of 400 landowners became the "elites of resistance". These 400 landowners in Kangondo strongly resisted the housing compensation scheme. The majority have several houses for rent and receive a sufficient income from rentals and therefore, their economic status is better than many in the neighbourhood. These 400 landowners pleaded to the minister of local governance to dismiss the decision to force them to accept the replacement houses for two main reasons. First, for them, compensation of houses alone would lead to impoverishment since they depend on income from renting out their houses and thus, they deserve a fair compensation in order to maintain their standard of living. Second, they requested compensation in cash because they found it unfair that the proposed houses and the resettlement site as compensation had been decided without their involvement.

"... But this project was proposed without their participation in the planning and design of the apartments to be constructed in Busanza..." 
The elite landowners claimed that the Expropriation Law stipulates that if compensation is in a form other than money, that must be agreed on and that was not the case in their resettlement. These landowners said that they do not resist public interest projects, but they believed that the project executors had deprived them of some of their key rights including the right to participate and to negotiate compensation.

The answer from the minister included two aspects that justified the reason why the project and the decisions made could not be set aside. First, the minister said:

"No person shall hinder the implementation of the program of expropriation in the public interest on the pretext of self-centred interests."

Second, the minister reminded the affected people that most of their houses are constructed too close to the wetland and thus their life faces the risk of disaster. Third, their neighbourhood is unplanned, and the houses were not built in conformance with construction regulations. Thus, the minister informed the affected households that the decision for relocation made by the district of Gasabo officials would not be changed and the only compensation package would be replacement houses. In general, local authorities repeated that position on several occasions (See https://www.ktpress. rw/2018/04/has-kigali-city-failed-to-explain-to-bannyahe-residents-the-relocation-plan/), that cash compensation is no longer an option available to informal settlement dwellers for the reasons of Fighting unsafe settlements. In his words, the mayor of Gasabo District made it clear that:

"We will not give money to just anybody since they may create another slum while we are Fighting against unsafe settlements."

For the elite of resistance group in Kangondo, legal recourse became the final option to claim rights and engagement in decision-making. The 400 landowners remained dissatisfied with the answers they received from local authorities, and so brought their case to the Court through their lawyer. They requested the Court to dismiss their resettlement process because it did not follow the legal provisions in place. The Court did not accept their case and suggested that they go back and negotiate with the relevant authorities. The 400 residents continued their struggle in the Court after being dissatisfied with the responses from the major of Kigali City, whose response was not different to that of the Minister. For this second time, the Court dismissed their case as a group claim and suggested these 400 landowners to refile their cases as individuals, a decision that they perceived to be unfair.

On 14 March 2020, the first stage of the demolition of the Kangondo neighbourhood started, while reports suggest that individuals envisioned to pursue the legal battle. However, this time the local authorities, in the district of Gasabo, advanced the argument for demolition to be mitigation of the risk of disasters from the expected heavy rain. Many of the evicted households were then forced to sign contracts to receive houses as the only option open to them and they received some amount of money to rent houses for three months while awaiting the completion of their new apartments.

Nikuze et al. [33] found that people in the households to be relocated perceived the use of disaster-risk label as a strategy to put them in a weak position for negotiations about their resettlement. This study suggests that the use of the disaster-risk label is probably going to be increasingly used to legitimise eviction. Although it might be true that some informal households are located in a naturally hazardous area, this study reveals that negotiations with affected people to allow them to voice their needs will still be crucial for local authorities to implement sustainable and equitable projects. Marx, Johnson, and Lwasa, [75] argued that even in the context of relocation realised to reduce exposure to disaster-risk, equitable resettlement outcomes should be given consideration. In-kind compensation is supported by many as a better strategy to mitigate post-relocation homelessness risk in comparison to cash compensation [76]. However, affected communities deserve participation to express their opinions and needs, and allow them to agree or not with the authorities over important decisions such as where to be resettled, what types of housing, cost, and other livelihood rehabilitation strategies. 


\section{Conclusions}

Urban redevelopment-induced displacement and resettlement processes, especially those involving informal settlements, continue to pose significant challenges to many governments in the Global South. The aim of this study was to analyse practices of participation by state actors' and the local responses to urban redevelopment-induced resettlements in Kigali, Rwanda. This study identifies factors including compliance with the national Expropriation Law, the participation of affected groups in resettlement related decision-making processes, details of the property valuation processes, compensation packages, community attributes, and how they trigger contestation between residents and local authorities. Overall, we show that local informal settlement dwellers are concerned about the deviations from the Expropriation Law, the lack of participation, lack of transparency in property valuation, and the unfair compensation packages offered in the resettlement processes. The consequences include increased perceptions of unfairness, livelihood risks, and distrust which fuel contestation and resistance attitudes among affected people. By producing insights into the interactions between local authorities and affected people over these raised concerns, the main contribution of this study lies in furthering our understanding of the various ways people claim spaces for participation in projects that affect their lives and livelihoods by directly confronting the authorities through contentions, legal action, and resistance, to change the status quo.

Our research provides evidence that local authorities deliberately delayed consultations and negotiations that, by law, should be initiated early in projects. In agreement with other studies [60], our study suggests that the ease with which such statutory safeguards are ignored relates to interests and pro-investment ideology. Deviations from legal requirements in the Expropriation Law, such as the lack of early negotiations, contributes to the feeling of marginalisation and exclusion from decision-making among affected landowners. Although in Mpazi a few landlords have accepted the offered houses, in Kangondo delaying consultation has increased resistance. Delayed negotiations led to damaged relations and trust as a result of lack of transparency and early participation. Rebuilding trust, to a level where negotiations can be successful ultimately requires much effort and time. Thus, following the formal process of early transparent negotiations can help avoid costly legal struggles and delays. Adopting early-stage negotiations and cooperation, before decision-making, should increase trust and ultimately the legitimacy of both the process and its outcomes. Our study suggests that the local government should adhere to the formal implementation procedures for land acquisition. Furthermore, clear and transparent guidelines for improved consultations in the implementation of compulsory in-kind compensation are essential for processes to become less adversarial. We observed a "decide-first, defend-after" decision-making approach in these redevelopment-induced resettlement projects. This approach, characterised by lack of participation, stimulates the affected residents to contest processes and their outcomes. This was especially evident in Kangondo, where the better-off landowners formed a powerful mobilisation and resistance group who claimed their rights to negotiate compensation in urban redevelopment-induced displacement. In addition, the perceived undervaluation and non-transparent property valuation as well as the government's imposition of replacement houses without the willingness to recognise the needs, interests, and rights of expropriated people has led to strong contestation. Thus, our study supports the view that governments should change their "decide-announce-defend" governance style [73] to a more inclusive and collaborative decision-making approach that is aligned with the formal procedures and legal instruments. We also see a clear need for governments to adopt co-design approaches involving affected communities on matters of houses design, which are fundamental to households' wellbeing. Furthermore, for owner-landlords who rely on income such as from housing rental, there is a strong incentive to mobilise and resist replacement houses because of the associated impoverishment risks. Therefore, paying attention to the socio-economic heterogeneity of the affected people is crucial to the design of compensation packages that match specific interests and needs. The loss of income from renting houses is also a serious concern among many informal households in Kigali and elsewhere. All forms 
of livelihoods, including housing as a source of income, need to be considered during resettlement processes and compensation regimes.

Although every project is unique, our findings offer more general insights into urban redevelopment governance and its implications for informal settlement dwellers. Furthermore, the two cases we presented are quite typical of urban redevelopment induced-displacement and resettlement processes that occur in other African cities. Our comparison of both forms of resettlement processes suggests that on-site relocation is likely to face fewer social conflicts than off-site relocation. Although both forms of resettlement lead to significant socio-economic changes, the location of a resettlement site is fundamental for livelihoods and general wellbeing. Residential location matters, especially for informal settlement dwellers, many of whom have strongly location-based incomes and may therefore experience high deprivation when displaced. Therefore, in addition to co-designing their houses, their active participation in selecting a resettlement site is crucial. Even so, the potential impacts of relocation need to be transparently and fully discussed and understood. If such impacts, such as loss of house rental, are not resolved, few households will be willing to willingly accept such changes. Therefore, we encourage more in-depth research into how such collaborative decision-making involving government authorities and affected households can be realised in Kigali and elsewhere. Future research should identify methodological approaches and tools to support the planning of resettlement sites and effective decision-making. Such planning instruments will help make the increasing scale of planned resettlement in Sub-Saharan Africa, whether due to infrastructure projects, disaster risk reduction, or climate change, both more equitable and more inclusive.

Author Contributions: Conceptualization, A.N., R.S., and J.F.; methodology, A.N.; data collection, A.N.; formal analysis, A.N.; writing-original draft, A.N.; writing—review and editing, A.N., R.S., and J.F.; supervision, J.F. and R.S. All authors have read and agreed to the published version of the manuscript.

Funding: This research received no external funding.

Acknowledgments: We are very grateful to all those who helped us in one way or the other to put together this paper. Specifically, we express our gratitude towards the staff of the City of Kigali for the support and all respondents in our study areas who enthusiastically responded to our questions. We would also like to extend our gratitude to the anonymous reviewers of this paper for their valuable and constructive comments for improvement.

Conflicts of Interest: The authors declare no conflict of interest.

\section{References}

1. Choi, Y.; Kim, H.; Woosnam, K.M.; Marcouiller, D.W.; Kim, H.J. Urban resettlement in residential redevelopment projects: Considering desire to resettle and willingness to pay. Neth. J. Hous. Environ. Res. 2015, 31, 213-238. [CrossRef]

2. Zheng, W.; Shen, G.Q.; Wang, H. A review of recent studies on sustainable urban renewal. Habitat Int. 2014, 41, 272-279. [CrossRef]

3. Strauch, L.; Takano, G.; Hordijk, M. Mixed-use spaces and mixed social responses: Popular resistance to a megaproject in Central Lima, Peru. Habitat Int. 2015, 45, 177-184. [CrossRef]

4. Wang, X.; Aoki, N. Paradox between neoliberal urban redevelopment, heritage conservation, and community needs: Case study of a historic neighbourhood in Tianjin, China. Cities 2019, 85, 156-169. [CrossRef]

5. Watson, V. African urban fantasies: Dreams or nightmares? Environ. Urban. 2014, 26, 215-231. [CrossRef]

6. Terminski, B. Development-Induced Displacement and Resettlement: An International Bibliography. SSRN Electron. J. 2013. [CrossRef]

7. Goodfellow, T. Rwanda's political settlement and the urban transition: Expropriation, construction, and taxation in Kigali. J. East. Afr. Stud. 2014, 8, 311-329. [CrossRef]

8. Mahalingam, A.; Vyas, A. Comparative Evaluation of Land Acquisition and Compensation Processes across the World. Econ. Polit. Wkly. 2011, 94-102.

9. Sengupta, U.; Sharma, S. No longer Sukumbasis: Challenges in grassroots-led squatter resettlement program in Kathmandu with special reference to Kirtipur Housing Project. Habitat Int. 2009, 33, 34-44. [CrossRef]

10. Sheppard, E.; Gidwani, V.; Goldman, M.; Leitner, H.; Roy, A.; Maringanti, A. Introduction: Urban revolutions in the age of global urbanism. Urban Stud. 2015, 52, 1947-1961. [CrossRef] 
11. Jordhus-Lier, D. Community resistance to megaprojects: The case of the N2 Gateway project in Joe Slovo informal settlement, Cape Town. Habitat Int. 2015, 45, 169-176. [CrossRef]

12. Kuyucu, T.; Ünsal, Ö. 'Urban Transformation' as State-led Property Transfer: An Analysis of Two Cases of Urban Renewal in Istanbul. Urban Stud. 2010, 47, 1479-1499. [CrossRef]

13. Noorloos, F.V.; Kloosterboer, M. Africa's new cities: The contested future of urbanisation. Urban Stud. 2018, 55, 1223-1241. [CrossRef] [PubMed]

14. Hall, R.; Edelman, M.; Scoones, I.; White, B.; Hall, R.; Edelman, M.; Scoones, I.; White, B. Resistance, acquiescence, or incorporation? An introduction to land grabbing and political reactions 'from below. J. Peasant Stud. 2015, 1-22. [CrossRef]

15. Dwivedi, R. Displacement, Risks and Resistance: Local Perceptions and Actions in the Sardar Sarovar. Dev. Chang. 1999, 30, 43-78. [CrossRef]

16. Yetiskul, E.; Kayasu, S.; Özdemir, S.S. Local responses to urban redevelopment projects: The case of Beyoğlu, Istanbul. Habitat Int. 2016, 51, 159-167. [CrossRef]

17. Unsal, B.O. State-led Urban Regeneration in Istanbul: Power Struggles between Interest Groups and Poor Communities. Hous. Stud. 2015, 30, 1299-1316. [CrossRef]

18. Tagliarino, N. National-Level Adoption of International Standards on Expropriation, Compensation, and Resettlement: A Comparative Analysis of National Laws Enacted in 50 Countries Across Asia, Africa, and Latin America. Ph.D. Thesis, University of Groningen, Groningen, The Netherlands, 2018.

19. Hui, E.C.; Bao, H.J.; Zhang, X. The policy and praxis of compensation for land expropriations in China: An appraisal from the perspective of social exclusion. Land Use Policy 2013, 32, 309-316. [CrossRef]

20. Dao, N. Dam development in Vietnam: The evolution of dam-induced resettlement policy. Water Altern. 2010, 3, 324-340.

21. German, L.; Schoneveld, G.; Mwangi, E. Contemporary Processes of Large-Scale Land Acquisition in Sub-Saharan Africa: Legal Deficiency or Elite Capture of the Rule of Law? World Dev. 2013, 48, 1-18. [CrossRef]

22. Schoneveld, G.C.; German, L. Translating Legal Rights into Tenure Security: Lessons from the New Commercial Pressures on Land in Ghana. J. Dev. Stud. 2013, 50, 187-203. [CrossRef]

23. Abebe, G.; Hesselberg, J. Community participation and inner-city slum renewal: Relocated people's perspectives on slum clearance and resettlement in Addis Ababa. Dev. Pr. 2015, 25, 551-562. [CrossRef]

24. Flyvbjerg, B.; Bruzelius, N.; Rothengatter, W. Projects and Risk; Cambridge University Press: Cambridge, UK, 2012; ISBN 9781848445352.

25. Gaventa, J. Finding the Spaces for Change: A Power Analysis. IDS Bull. 2006, 37, 23-33. [CrossRef]

26. Zoomers, A.; van Noorloos, F.; Otsuki, K.; Steel, G.; van Westen, G. The Rush for Land in an Urbanizing World: From Land Grabbing Toward Developing Safe, Resilient, and Sustainable Cities and Landscapes. World Dev. 2017, 92, 242-252. [CrossRef]

27. Manirakiza, V.; Ansoms, A. 'Modernizing Kigali': The struggle for space in the Rwandan urban context. In Losing Your Land: Dispossession in the Great Lakes; Ansoms, A., Thea, H., Eds.; James Currey: Rochester, NY, USA, 2014.

28. Uwayezu, E.; Vries, W.T. Can In-Kind Compensation for Expropriated Real Property Promote Spatial Justice? A Case Study Analysis of Resettlement in Kigali City, Rwanda. Sustainability 2020, 12, 3753. [CrossRef]

29. Chan, E.H.; Yung, E. Is the development control legal framework conducive to a sustainable dense urban development in Hong Kong? Habitat Int. 2004, 28, 409-426. [CrossRef]

30. Wu, F. Residential relocation under market-oriented redevelopment: The process and outcomes in urban China. Geoforum 2004, 35, 453-470. [CrossRef]

31. Liu, Y.; Lin, Y.; Fu, N.; Geertman, S.; van Oort, F. Towards inclusive and sustainable transformation in Shenzhen: Urban redevelopment, displacement patterns of migrants and policy implications. J. Clean. Prod. 2018, 173, 24-38. [CrossRef]

32. Patel, S.; Sliuzas, R.; Mathur, N. The risk of impoverishment in urban development-induced displacement and resettlement in Ahmedabad. Environ. Urban. 2015, 27, 231-256. [CrossRef]

33. Nikuze, A.; Sliuzas, R.V.; Flacke, J.; van Maarseveen, M.F. Livelihood impacts of displacement and resettlement on informal households-A case study from Kigali, Rwanda. Habitat Int. 2019, 86, 38-47. [CrossRef]

34. Hao, P.; Sliuzas, R.; Geertman, S. The development and redevelopment of urban villages in Shenzhen. Habitat Int. 2011, 35, 214-224. [CrossRef] 
35. Shin, H.B. Residential Redevelopment, and the Entrepreneurial Local State: The Implications of Beijing's Shifting Emphasis on Urban Redevelopment Policies. Urban Stud. 2009, 46, 2815-2839. [CrossRef]

36. Tagliarino, N.K. The Status of National Legal Frameworks for Valuing Compensation for Expropriated Land: An Analysis of Whether National Laws in 50 Countries/Regions across Asia, Africa, and Latin America Comply with International Standards on Compensation Valuation. Land 2017, 6, 37. [CrossRef]

37. Dziwornu, A.; Ko, V. Local participation, institutions, and land acquisition for energy infrastructure: The case of the Atuabo gas project in Ghana. Energy Res. Soc. Sci. 2018, 41, 191-198.

38. Hu, Y.; Hooimeijer, P.; Bolt, G.; Sun, D. Uneven compensation, and relocation for displaced residents: The case of Nanjing. Habitat Int. 2015, 47, 83-92. [CrossRef]

39. Tadgell, A.; Doberstein, B.; Mortsch, L. Principles for climate-related resettlement of informal settlements in less developed nations: A review of resettlement literature and institutional guidelines. Clim. Dev. 2017, 10, 1-14. [CrossRef]

40. Patel, S.; D'Cruz, C.; Burra, S. Beyond evictions in a global city: People-managed resettlement in Mumbai. Environ. Urban. 2002, 14, 159-172. [CrossRef]

41. Correa, E.; Ramírez, F.; Sanahuja, H. Populations at Risk of Disaster A Resettlement Guide; The World Bank and Global Facility for Disaster Reduction and Recovery: Washington, DC, USA, 2011.

42. Asif, M. Why Displaced Persons Colonies Reject Project Resettlement. Econ. Polit. Wkly. 2000, 35, $2005-2008$.

43. Loures, L.; Crawford, P.A.T. Democracy in progress: Using public participation in post-industrial landscape (re)-development. WSEAS Trans. Environ. Dev. 2008, 9, 794-803.

44. Owen, J.R.; Vivoda, V.; Kemp, D. Country—Level governance frameworks for mining-Induced resettlement. Environ. Dev. Sustain. 2019, 22, 4907-4928. [CrossRef]

45. Arnstein, S.R. A Ladder of Citizen Participation. J. Am. Inst. Planners 1969, 35, 216-224. [CrossRef]

46. Choguill, M.B. A ladder of community participation for underdeveloped countries. Habitat Int. 1996, 20, 431-444. [CrossRef]

47. Lawrence, A. Ethics Place and Environment 'No Personal Motive? Volunteers, Biodiversity, and the False Dichotomies of Participation. Ethics Plance Environ. 2006, 9, 280-298.

48. Luyet, V.; Schlaepfer, R.; Parlange, M.B.; Buttler, A. A framework to implement Stakeholder participation in environmental projects. J. Environ. Manag. 2012, 111, 213-219. [CrossRef] [PubMed]

49. Nolte, K.; Voget-Kleschin, L. Consultation in Large-Scale Land Acquisitions: An Evaluation of Three Cases in Mali. World Dev. 2014, 64, 654-668. [CrossRef]

50. Zoomers, A. Globalisation and the foreignisation of space: Seven processes driving the current global land grab. J. Peasant. Stud. 2010, 37, 429-447. [CrossRef]

51. Ijabadeniyi, A.; Vanclay, F. Socially Tolerated Practices in Environmental and Social Impact Assessment Reporting: Discourses, Displacement, and Impoverishment. Land 2020, 9, 33. [CrossRef]

52. Butcher, S.; Frediani, A.A. Insurgent citizenship practices: The case of Muungano wa Wanavijijiin Nairobi, Kenya. City 2014, 18, 119-133. [CrossRef]

53. Uwayezu, E.; de Vries, W.T. Scoping land tenure security for the poor and low-income urban dwellers from a spatial justice lens. Habitat Int. 2019, 91, 102016. [CrossRef]

54. Swyngedouw, E.; Moulaert, F.; Rodriguez, A. Neoliberal Urbanization in Europe: Large-Scale Urban Development Projects and the New Urban Policy. Antipode 2002, 34, 542-577. [CrossRef]

55. De vos, R.; Delabre, I. Spaces for participation and resistance: Gendered experiences of oil palm plantation development. Geoforum 2018, 96, 217-226. [CrossRef]

56. Baud, I.; Nainan, N. "Negotiated spaces” for representation in Mumbai: Ward committees, advanced locality management and the politics of middle-class activism. Environ. Urban. 2008, 20, 483-499. [CrossRef]

57. Cornwall, A. Making Spaces, Changing Places: Situating Participation in Development; Institute of Development Studies: Brighton, UK, 2002.

58. Aarts, N.; Leeuwis, C. Participation and Power: Reflections on the Role of Government in Land Use Planning and Rural Development. J. Agric. Educ. Ext. 2010, 16, 131-145. [CrossRef]

59. Zhuang, T.; Qian, Q.; Visscher, H.; Elsinga, M.; Wu, W. The role of stakeholders and their participation network in decision-making of urban renewal in China: The case of Chongqing. Cities 2019, 92, 47-58. [CrossRef]

60. Schoneveld, G.C. Host country governance and the African land rush: 7 reasons why large-scale farmland investments fail to contribute to sustainable development. Geoforum 2017, 83, 119-132. [CrossRef] 
61. Hordijk, M.; Sara, L.M.; Sutherland, C.G.; Scott, D. Participatory Instruments and Practices in Urban Governance. In Geographies of Urban Governance; Springer Science and Business Media LLC: Berlin/Heidelberg, Germany, 2015; pp. 127-146.

62. Miraftab, F. Invited and Invented Spaces of Participation: Neoliberal Citizenship and Feminist's Expanded Notion of Politics. Wagadu 2004, 1, 1-7.

63. Miraftab, F.; Wills, S. Insurgency and Spaces of Active Citizenship. J. Plan. Educ. Res. 2005, 25, $200-217$. [CrossRef]

64. Manirakiza, V.; Mugabe, L.; Nsabimana, A.; Nzayirambaho, M. City Profile: Kigali, Rwanda. Environ. Urban. Asia 2019, 10, 290-307. [CrossRef]

65. Goodfellow, T.; Smith, A. From Urban Catastrophe to 'Model' City? Politics, Security and Development in Post-conflict Kigali. Urban Stud. 2013, 50, 3185-3202. [CrossRef]

66. Uwayezu, E.; de Vries, W.T. Expropriation of Real Property in Kigali City: Scoping the Patterns of Spatial Justice. Land 2019, 8, 23. [CrossRef]

67. Law, No.32/2015 of 11/06/2015 Relating to Expropriation in the Public Interest; Government of Rwanda: Kigali, Rwanda, 2015; pp. 15-53.

68. Wakhungu, J.; Huggins, C.; Nyukuri, E.; Lumumba, J. Approaches to Informal Urnan Settlements in Africa: Experiences from Kigali and Nairobi; African Centre for Technology Studies: Nairobi, Kenya, 2010.

69. Yu-Hung, H. Assembling Land for Urban Development: Issues and Opportunities. In Analyzing Land Redevelopment Economics, Law, and Collective Action; Yu-Hung, Y., Needham, B., Eds.; Lincoln Institute of Land Policy: Cambridge, UK, 2007; pp. 13-25.

70. Esmail, S.; Corburn, J. Struggles to remain in Kigali's "unplanned" settlements: The case of Bannyahe. Environ. Urban. 2019, 32, 19-36. [CrossRef]

71. Hsieh, H.-F.; Shannon, S.E. Three Approaches to Qualitative Content Analysis. Qual. Heal. Res. 2005, 15, 1277-1288. [CrossRef] [PubMed]

72. Deininger, K.; Selod, H.; Burns, A. The Land Governance Assessment Framework: Agriculture and Rural Development; The World Bank: Washington, DC, USA, 2012.

73. Cao, Y.; Dallimer, M.; Stringer, L.; Bai, Z.; Siu, Y.L. Land expropriation compensation among multiple stakeholders in a mining area: Explaining "skeleton house" compensation. Land Use Policy 2018, 74, 97-110. [CrossRef]

74. Liu, T.; Yau, Y. Institutional inadequacies and successful contentions: A case study of the LULU siting process in Hong Kong. Habitat Int. 2014, 44, 22-30. [CrossRef]

75. Marx, C.; Johnson, C.; Lwasa, S. Multiple interests in urban land: Disaster-induced land resettlement politics in Kampala resettlement politics in Kampala. Int. Plan. Stud. 2020, 1-13.

76. Cernea, M.M. African Involuntary Population Resettlement in a Global Context; The World Bank: Washington, DC, USA, 1997.

(C) 2020 by the authors. Licensee MDPI, Basel, Switzerland. This article is an open access article distributed under the terms and conditions of the Creative Commons Attribution (CC BY) license (http://creativecommons.org/licenses/by/4.0/). 